\title{
MELVILLE J. HERSKOVITS
}

On February 25, 1963, there died in Evanston, Illinois, at the age of 68, Melville J. Herskovits, professor of anthropology and African Affairs at Northwestern University and one of the consulting editors of this journal. At the time of his death, Dr. Herskovits could look back on a long and fruitful career. Born in Bellefontaine, Ohio, on September 10, 1895, Herskovits completed his undergraduate studies at the University of Chicago (Ph.B., 1920), his graduate work in anthropology at Columbia University (M.A. 1921; Ph.D. 1923). In 1923, he began his intensive work on the physical characteristics of the American Negro which laid the foundations of a life-time of field work and theoretical concern with African and AfroAmerican cultures. His Anthropometry of the American Negro (1930) demonstrated the great degree of racial mixture among American Negroes; his Myth of the Negro Past (1941) proved a milestone in the understanding of the cultural position of the American Negro.

In his field work, he was staunchly supported by his wife Frances, whom he married in 1924. Frances Herskovits also co-authored a number of books, such as Rebel Destiny (1934), on the Saramacca tribe of Dutch Guiana; Trinidad Village (1947); and the recent Dahomean Narrative (1958). Melville Herskovits alone wrote Life in a Haitian Valley (1937) and Dahomey: An Ancient West African Kingdom (1938). For a long time the only Africanist in the United States, he not only became the dean of African studies in this country, but had the great satisfaction of witnessing the development and success of a thriving program of Africanist training at Northwestern University.

Two books, Economic Anthropology (1949) and Man and his Works (1948), embody Herskovits' theoretical insights. His latest book, The Human Factor: Changing Africa (1962), summarized his experience in the African field.

Dr. Herskovits' passing means that the international scientific community has lost a forceful protagonist of international cooperation and exchange. 
Anthropology in the United States, as elsewhere, will badly miss his intellectual and organizational vigor. This journal mourns a helpful and devoted friend.

ERIC R. WOLF

Universtity of Michigan 